\title{
Recent Trends of the Temperature Field in the Northern Hemisphere
}

\author{
By Nobushige Mori* \\ Meteorological Research Institute, Tokyo \\ (Manuscript received 28 March 1978, in revised form 4 July 1978)
}

\begin{abstract}
Recent trends for changes of the temperature field in the northern hemisphere are described by using the annual-mean data for 25 years (1950-1974) in the lower layer (1,000$500 \mathrm{mb}$ ) and for 20 years (1956-1975) in the upper layer $(500-100 \mathrm{mb})$. We expressed a given time series in terms of Tchevychef's orthogonal polynomial, and it was decided by using a statistical test for goodness of fit how many terms should be chosen in the polynomial. The usual type transformed from the above polynomial was used as a trend or a measure for the change of a given time series.

As for long-term-mean temperature fields at first, a characteristic aspect in the upper layer is shown in comparison with that in the lower layer. The zonal-mean temperature in $80^{\circ} \mathrm{N}$ was a linearly upward change in the lower layer but a linearly downward change in the upper layer. In the lower layer, it has become warmer in the west-hemispherical side of $80^{\circ} \mathrm{N}$, where a cold-air source was located, and colder in the east-hemispherical side of $80^{\circ} \mathrm{N}$ where it was a warmer region. It was assumed that the area between $80^{\circ} \mathrm{N}$ and $30^{\circ} \mathrm{N}$ could be classified into three latitudinal zones on trend types and those correspondence between the lower and upper layers. The first is $80^{\circ} \mathrm{N}$, the second $70^{\circ} \mathrm{N}$ and $60^{\circ} \mathrm{N}$ and the third south of $50^{\circ} \mathrm{N}$, and features in each of the zones are mentioned. The trend of areal-mean temperature was expressed by a quadratic formula in the lower layer and by the third-order formula in the upper layer. The changes of the meridional and zonal gradients of temperature both have generally a descending trend in the lower layer and an ascending trend in the upper layer. Namely, the temperature field has changed as becoming flatter in the lower layer and steeper in the upper layer, and it is suggested energetically that the lower layer has lost zonal and eddy available potential energies both and the upper layer has acquired those.
\end{abstract}

\section{Introduction}

Although climatic studies for temperature belonged to the category of regional trends and fluctuations before 1940s, Willett (1950) discussed the variation of zonally-averaged surface temperature at stations. within a $10^{\circ}$-latitude width. His work took away the classification form being called as climatic division in climatology and led to a new way in consideration on the climatic change of a hemispherical or global scale. Mitchell (1963) improved Willett's treatment with respect to areal mean and showed that there was qualitatively no difference between both temperature trends in the northern and southern hemispheres.
A principal source of energy supplied to the atmosphere is solar radiation, and global-mean temperature is directly influenced by the change of its intensity which depends upon the changes of amounts of dust, carbon dioxide, water vapor and so on in the atmosphere. It is very important to study the various relationships between globalmean temperature and solar radiation, and many papers relative to such the problem have been published so far. For example, Callendar (1961) considered speculatively that the observed distribution of temperature trends over the earth could be reasonably explained by the variation of atmospheric carbon dioxide rather than atmospheric dust up to 1950 s and, more recently, Budyko (1977) emphasized that an increasing anthropogenic aerosol has produced much effect 
on global-mean temperature rather than that of carbon dioxide recently. Solar radiative energy, in addition, is stored at the earth's surface to act as a secondary source on the atmosphere, and it is very different and complicated in accordance with surface condition how the energy is stored. Hence, it is considered to interact complicatedly between the atmosphere and earth's surface in a region where various types of surface condition exist together. Such the situation, that is, four ingredients of the atmosphere, the ocean, ice and land co-exist in the circumarctic region as specified by Otterman (1976). According to his view, the complicated thermal budget in the above region reflects sensitively on climatic change.

Angell and Korshover (1977) found out that temperature fields were largely disturbed from the surface to the upper layer in the north and south extratropical regions at the time of the eruption of Mt. Agung. In their results, the produced disturbances by the eruption disappeared apparently after a few years and so it is assumed that the eruption of Mt. Agung did not yield so much effect on the temperature fields to give rise to a long-term trend.

Recently, van Loon and Williams (1976a, 1976b) discussed the difference between the two changes of surface temperature in the period 1900-1941 and in the period 1942-1972 from the standpoint of a hemispherical scale. They suggested that the changes were upward in the former and downward in the latter and, moreover, that such the difference depended upon the amount of sensible-heat flux associated with the intensity of the general circulation. We may presume from their analytical results that if a type of circulation regimes is established once, the regime has a durable trend for a few decade years or more, probably to be maintained by force from external systems for the atmosphere. And then, the Icelandic and Aleutian lows taken notice by them are precisely located in such the region as pointed out by Otterman (1976). There were some changes in trends for climatic variables of zonal flow, the arctic sea-ice area, the centers of the subtropical high pressure belt and the frequencies of blocking anticyclone between 1960s and 1970s after Painting (1977). He suggested the possibility of a lag effect of sea surface temperature on the atmosphere that the persistent outbreak of cold air in a strong blocking situation, prevailed over Greenland in 1960s, reduced the sea surface temperature in the Atlantic Ocean and this cooler sea water contributed to the down trend of mid-latitude surface temperature in 1970s. It is undoubted that the trend of a temperature change in a hemispherical scale is closely related to the change of a circulation regime.

Now, we still are insufficient for observational information connected with the change of a temperature field to become reference standards in certifying various views and conceptions for the long-term variation in the atmospheric temperature field. Such the present situation is due to the difficulty for the collection of long-term data, particularly in the upper layer. Our purpose is to describe some aspects of the changes in the lower and upper temperature fields from the viewpoint of a hemispherical scale.

\section{Data and analysis method}

Chosen periods are 25 years from the March 1950 to the February 1975 for a lower layer and 20 years from the March 1956 to the February 1976 for an upper layer. Basic data are the monthly-mean values of surface pressure, 500 and $100 \mathrm{mb}$ heights which have been collected and made to be available in the Long Range Forecast Section of Japan Meteorological Agency (JMA). The data for $100 \mathrm{mb}$ height after the August 1970 were obtained from the information based upon the objective analysis in the Electronic Computation Center of JMA. The data were given at each grid point of $10^{\circ}$ interval in latitude and longitude to the north of $30^{\circ} \mathrm{N}$ and in part at $20^{\circ} \mathrm{N}$.

We computed from monthly-mean $500-100 \mathrm{mb}$ thickness as the temperature in an upper layer and so the upper layer includes the upper troposphere and a part of the lower stratosphere. The temperature in a lower layer, which corresponds to the lower troposphere, was converted from $1,000-500 \mathrm{mb}$ thickness, which was estimated by using the monthly-mean values of surface pressure and $500 \mathrm{mb}$ height. Annual-mean data were made by averaging from March to the coming February.

To classify objectively pressure patterns, Friedman (1955) used the sign and magnitude of coefficients in a polynomial by Tchevychef's orthogonal function which is invariant after the decision of sampling points. The use of the expansion by Tchevychef's orthogonal function is convenient for a limited data domain to express mathematically variation in space or time though employing often Fourier expansion in a cyclic or periodical data domain. The following method (Suzuki, 1968; Japanese Standards As- 
sociation, 1972) was adopted for determining a trend in a given time series. Denoting $T_{t}$ a value in a given time series and $\xi_{i}, t$ Tchevychef's orthogonal function, we can get a set of orthogonal polynomials with $\xi_{i}, t$ as a fixed variate, that is,

$$
\begin{aligned}
& T_{t}=B_{1} \xi_{1, t}+B_{2} \xi_{2, t}+\cdots+B_{i} \xi_{i, t} \\
&(t=1,2, \cdots \text { and } N)
\end{aligned}
$$

where subscripts $i$ and $t$ represent the order of Tchevychef's orthogonal function and the ordinal number for arrangement assigning unity to the first datum, by turns, $2,3, \ldots$ and $N$ in a given time series respectively, and $N$ is the total number of data. Here, we can decide the magnitude of coefficients $B_{1}, B_{2}, \ldots$ and $B_{i}$ as being independent upon each other by solving the above set of orthogonal polynomials because of the orthogonal relationship among $\xi_{1}, t, \xi_{2}, t, \ldots$ and $\xi_{i}, t$. Next, the test of goodness of fit was tried by means of variance analysis for deciding how many terms should be taken by turns from the first term in the solved orthogonal polynomial as satisfying significance level $\alpha$ in a given time series. $\alpha=5 \%$ was chosen in this case. Thereafter, the above orthogonal polynomial was transformed into usual polynomial with $t$ as a fixed variate, and that is

$$
T_{t}=A_{0}+A_{1} t+A_{2} t^{2}+\cdots+A_{p} t^{p}
$$

where $p$ shows the highest order of chosen terms by the test of variance analysis, and we defined the usual polynomial as the regression formula expressing the trend of a given time series. Thereupon, $A_{0}$ in the usual polynomial is the total of the zero-order values for $t$ in $\sum_{i=1}^{p} B_{i} \xi_{i, t}$ and likewise, in general, $A_{k}$ is easily obtained by summing up the $k^{\text {th }}$-order values for $t$ in $\sum_{i=k+1}^{p} B_{i} \xi_{i, t}(k=0,1, \cdots$ and $p-1)$.

We tried also the test of confidence coefficient for each of $B_{i}$ in Tchevychef's orthogonal polynomial and marked in particular a single asterisk (the 90 to $95 \%$ confidence coefficient) and double asterisks (the $97.5 \%$ confidence coefficient and more) to $B_{i}$ with higher confidence coefficient. Symbol $S$ represented in the latter figures means the root mean square of the difference between data and the values calculated from an obtained regression formula, from which $S$ gives a scattering degree of data.

As a matter of course, the following expression was used in performing an areal-mean operation to a quantity $X(\lambda, \varphi)$ given at each grid point of $10^{\circ}$ in latitude and longitude.

$$
\begin{aligned}
\hat{X} & =\int_{\varphi} \int_{\lambda} X d \lambda d \varphi / \int_{\varphi} \int_{\lambda} d \lambda d \varphi \\
& =\frac{1}{36} \sum_{\varphi=\varphi_{s}}^{\varphi_{n}} \sum_{m=1}^{36}\left[X_{m},{ }_{\varphi} \cos \varphi\right] / \sum_{\varphi=\varphi_{s}}^{\varphi_{n}}[\cos \varphi]
\end{aligned}
$$

where $\lambda, \varphi, \varphi_{n}$ and $\varphi_{s}$ represent longitude, latitude, the northern-boundary latitude and the southern-boundary latitude in an integrated domain respectively.

It was given notice by van Loon and Williams (1976a) that the International Barometric Conversion was introduced to the stations on the Asian highland in 1956. We judged that the three grid points on the $40^{\circ} \mathrm{N}$-circle corresponded to the above introduction in our case. The time series of surface pressure at $40^{\circ} \mathrm{N}, 90^{\circ} \mathrm{E}$ are illustrated in Fig. 1 as the example, and broken lines in the figure show the mean values for the respective 7 years. As for the difference between the mean values before and after the introduction of the conversion, the former is higher than the latter in warm season and its relation is reversed

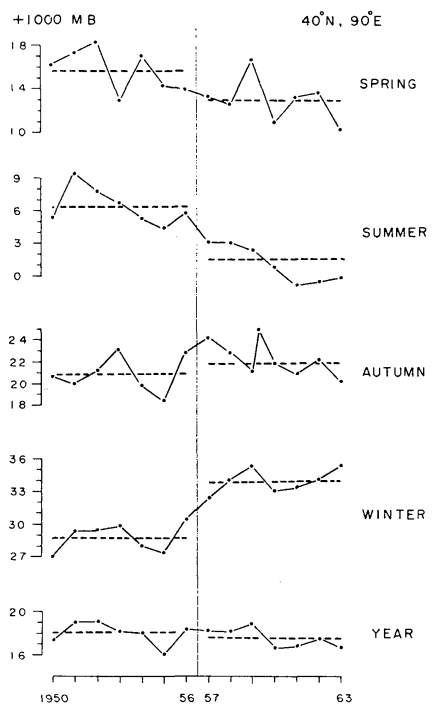

Fig. 1 An example for the variation course of the surface pressure on the Asian highland in connection with the introduction of the International Barometric Conversion pointed out by van Loon and Williams (1976a). The left and right sides of a perpendicular thin line are 7 years before and after the introduction of the above conversion respectively. Dotts and solid lines show the year-toyear variation of seasonal- and annual-mean surface pressures and horizontal broken lines, mean values in each of 7 years. 
in cold season as being obvious in Fig. 1. The difference in the annual mean is very small and has $0.5 \mathrm{mb}$ in magnitude though being very large in summer and winter. Assuming to adopt the value $0.5 \mathrm{mb}$ as the previous difference, this value influences $0.25^{\circ} \mathrm{C}$ in magnitude on the temperature converted from $1,000-500 \mathrm{mb}$ thickness at a rough estimate. Similarly, such the difference at the other two grid points were nearly same as or less than this value. Then, it may be allowed to ignore such the difference in the following discussion based upon an annual and, in addition, zonal or areal mean.

\section{Time-mean temperature fields}

In this section, we would describe general aspects for the time-mean temperature fields in the lower and upper layers and consider the temperature field variation in high latitude where is interesting as a cold-air source.

Fig. 2a shows the 25-year-mean temperature field in the lower layer. We can see at a glance from the figure that the basic field of temperature in the lower layer is a familiar pattern like a circumpolar wave shape. A cold-air center was situated in $80^{\circ} \mathrm{N}, 90^{\circ} \mathrm{W}$ north of Canada and its reading was $-24.5^{\circ} \mathrm{C}$. The isothermal line of $8^{\circ} \mathrm{C}$ was drawn from the south-western part of the Pacific Ocean to West Pakistan along a latitudinal circle near $20^{\circ} \mathrm{N}$ to $25^{\circ} \mathrm{N}$, and so the temperature difference between the polar region and there amounted to $32.5^{\circ} \mathrm{C}$ in magnitude. On the other hand, the feature of the 20year-mean temperature field in the upper layer is conspicuously different from that in the lower layer as illustrated in Fig. 2b. The cold-air center in the upper layer holded a position at $70^{\circ} \mathrm{N}, 100^{\circ} \mathrm{E}$ in the northern part of the central Siberia, where is nearly equivalent to the opposite side of that in the lower layer with respect to the pole. Furthermore, a striking aspect in the upper temperature field is characterized by being eccentric apart from that in the lower layer, and the isothermal lines in the upper layer were closely drawn in the eastern hemisphere but scarcely in the western hemisphere, so that the stationary disturbances in the temperature field were predominant in the eastern hemisphere only. It is an interest by what such the pattern is caused ánd maintained as a normally stationary disturbance in the upper temperature field. Maximum and minimum temperature readings were the value of $-44.9^{\circ} \mathrm{C}$ over the southern part

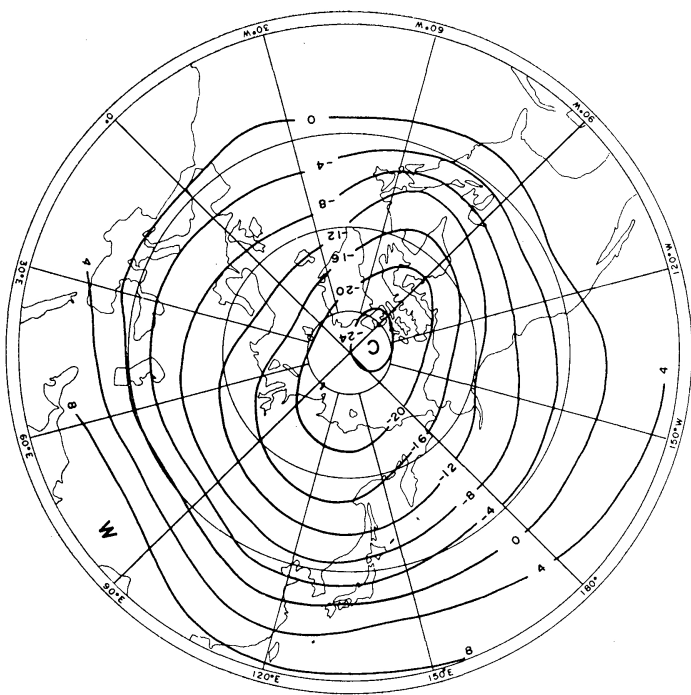

Fig. 2a The time-mean temperature field in the lower layer for $1950-1974\left({ }^{\circ} \mathrm{C}\right)$.

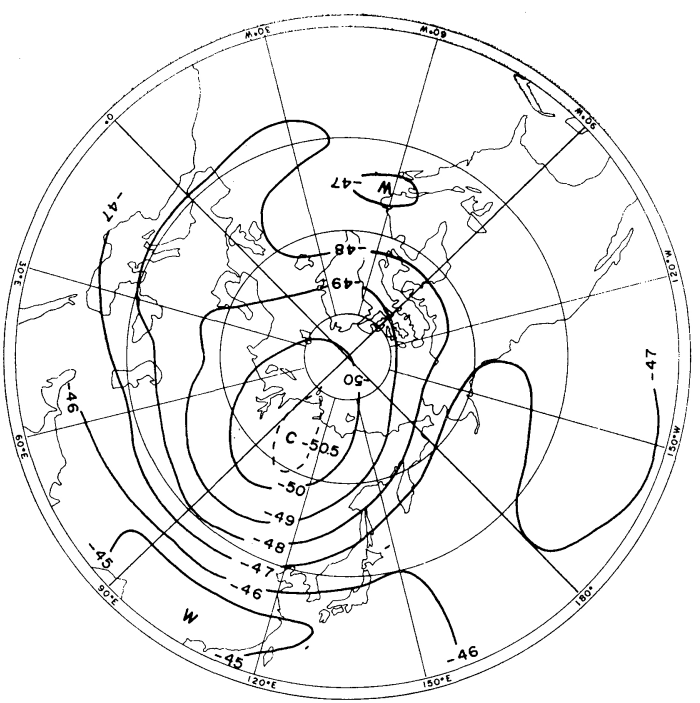

Fig. $2 b$ The time-mean temperature field in the upper layer for $1956-1975\left({ }^{\circ} \mathrm{C}\right)$.

of China and the value of $-50.6^{\circ} \mathrm{C}$ over the central Siberia respectively, and so the difference between both was $5.7^{\circ} \mathrm{C}$ in magnitude which was nearly one-sixth of that in the lower layer.

Figs. $3 \mathrm{a}$ and $3 \mathrm{~b}$ show the patterns of the zonal-mean anomalies corresponding to Figs. 2a and $2 \mathrm{~b}$ respectively, from which we could distinctively see warmer and colder areas. As for the lower layer, it is revealed in Fig. 3a that two positive-anomaly areas covered over most of the Eurasian Continent and the western North 


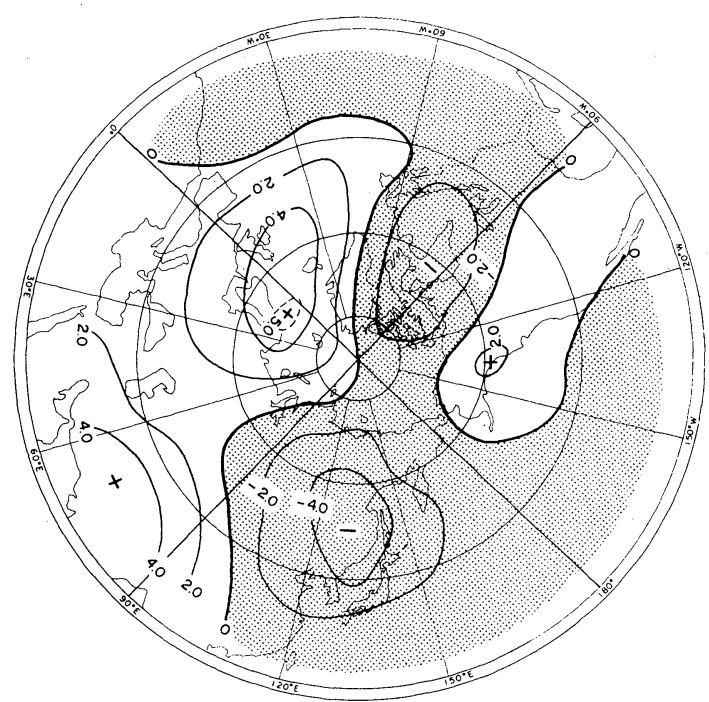

Fig. 3a The anomaly distribution from the zonal-mean temperature in the same as Fig. $2 \mathrm{a}\left({ }^{\circ} \mathrm{C}\right)$.

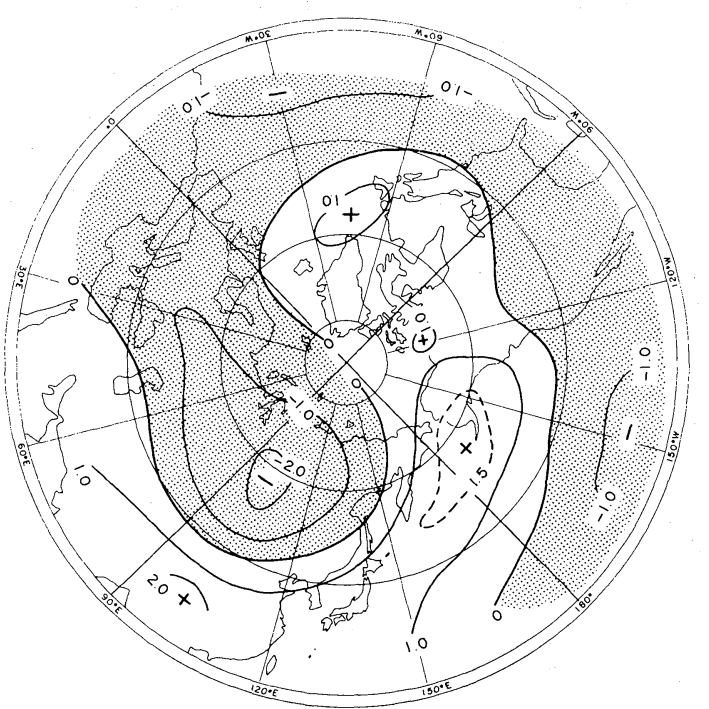

Fig. 3b As in Fig. 3a except Fig. 2b.

America and, meanwhile, a negative-anomaly area extended from the South Atlantic Ocean to the Pacific Ocean through the eastern North America and the Far East. The stationary disturbance with a wave-number-2 shape was predominant in the lower layer. As for the upper layer, as seen in Fig. 3b, the positive anomaly occupied the region from the North Atlantic Ocean to the southern part of Asia through Canada, Aleutian and the north-western Pacific Ocean, and the negative anomaly covered over the region from the northern part of Asian Con- tinent to the southern part of the western hemisphere through the European area. The stationary disturbance in the upper layer had the pattern of wave number 1. From Figs. $3 a$ and $3 b$, we can find good correspondence between the lowerand upper-anomaly centers. Three combinations, that is, the lower Far East and the upper central Siberia in negative anomaly, the lower off-Europe and the upper off-Greenland, the lower Alaska and the upper Aleutian in positive anomaly, are certified, but the lower negative anomaly over Hadson Bay lacks in the upper layer. Their upward axes all inclined nearly to $30^{\circ}$ westward in longitude.

The cold-air outbreak from the arctic region has often and seriously influenced on our social life and so one pays much attention to a matter how temperature variates there locally and in the region as a whole also. Fig. 4 a shows two zonal distributions of the linear regression coefficients for temperature trends and the zonal-mean anomalies of the corresponding temperature to Fig. $3 a$ along the $80^{\circ} \mathrm{N}$ circle in the lower layer. The correlation coefficient between both takes -0.72 in value with the $0.1 \%$ significance level. It is easily known to have become warmer in a

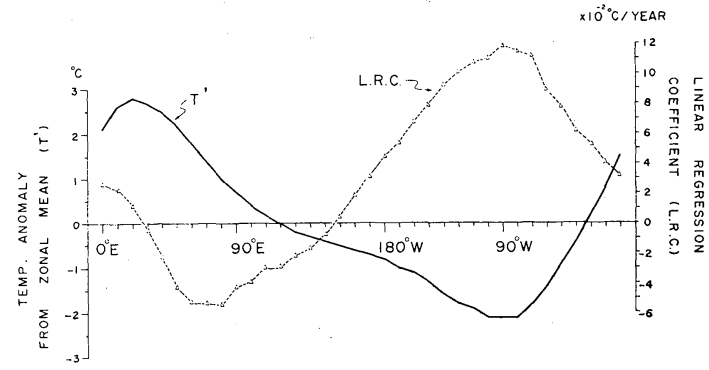

Fig. $4 \mathrm{a}$ The zonal distributions of the temperature anomalies from a zonal mean with a solid line and the linear regression coefficients with triangles and broken lines along the $80^{\circ} \mathrm{N}$ circle in the lower layer.

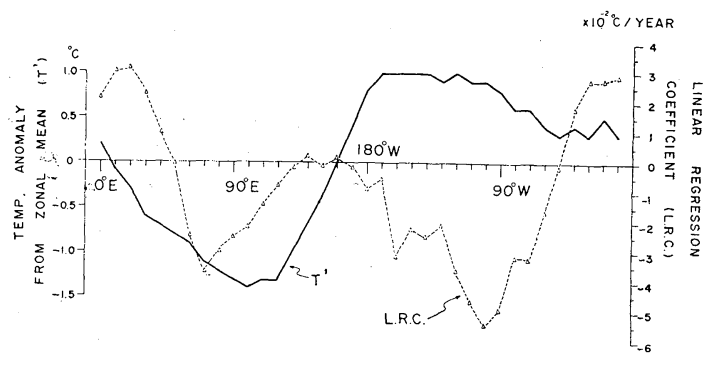

Fig. $4 \mathrm{~b}$ As in Fig. 4a except in the upper layer. 


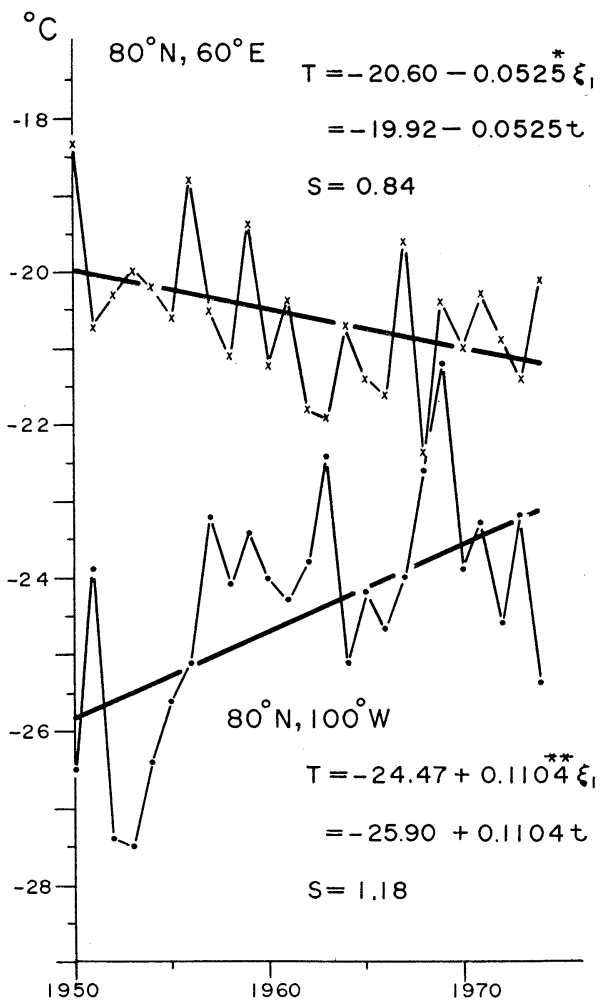

Fig. 5 Temperature trends with thick lines and year-to-year temperature changes with crosses and solid lines at $80^{\circ} \mathrm{N}$, $60^{\circ} \mathrm{E}$ and with dotts and solid lines at $80^{\circ} \mathrm{N}, 100^{\circ} \mathrm{W}$.

cold region or in most of the western hemisphere and colder in a warmer region or in most of the eastern hemisphere. We can say in general that the zonal distribution of the temperature along the $80^{\circ} \mathrm{N}$ circle has become flatter when taking a linear change as described later. The above statement is a consideration based upon the zonal-mean anomalies in the time-mean field. So the aspects at $80^{\circ} \mathrm{N}, 60^{\circ} \mathrm{E}$, and $80^{\circ} \mathrm{N}, 100^{\circ} \mathrm{W}$, where had maximum decreasing and increasing trends respectively, are shown in Fig. 5 as one concrete example as to the above spatial change. The temperatures at both grid points were sudden in a change and have recently become comparable in value with each other though year-to-year fluctuations both were very large. Likewise, Fig. $4 \mathrm{~b}$ shows the same relation in the upper layer as in Fig. $4 \mathrm{a}$ but along the $70^{\circ} \mathrm{N}$ circle where the cold-air center in the upper layer was located. The upper temperature change was a decreasing trend in the most part of positive- and negativeanomaly regions both. The correlation coefficient between the trends and anomalies in the upper layer is very small $(-0.17)$ and so we have no significant comment.

\section{The trends of zonal- and areal-mean temperatures}

The zonal- and areal-mean temperature trends in the lower layer are shown by thick lines in Fig. 6a and those regression formulae also are written in it. We can find out the following aspects about the temperature trends from the figures. The first is a remarkably linear-ascending trend in $80^{\circ} \mathrm{N}$ though having fluctuated very largely from year to year in comparison with the other latitudes, and its regression coefficient is of high significance with one asterisk. Secondary, the two trends in $60^{\circ} \mathrm{N}$ and $70^{\circ} \mathrm{N}$ are shown by a linearly descending type. The trends in the latitudinal zone between $50^{\circ} \mathrm{N}$ and $30^{\circ} \mathrm{N}$ have the third form expressed by a quadratic formula and their coefficients all have high confidence coefficient. Since all of the second-order coefficients are negative, the temperatures in the above three latitudes have changed upwards in the former half of this time series and downwards in the latter half. The areal-mean temperature change between $85^{\circ} \mathrm{N}$ and $25^{\circ} \mathrm{N}$ has the same third form as the trends in the south three latitudes where holds a part of about two-third of the domain treated by us.

Areal-mean temperature trends have already revealed in a few papers. For example, van Loon and Williams (1976a, 1976b) estimated the values of $-0.21^{\circ} \mathrm{C}$ and $-0.19^{\circ} \mathrm{C}$ in winter and summer respectively as the average change of surface temperature for 31 years between $15^{\circ} \mathrm{N}$ and $80^{\circ} \mathrm{N}$. When making our value reducing to their unit, it takes the value of $-0.27^{\circ} \mathrm{C}$ from the linear regression coefficient, which is the coefficient of $\xi_{1}$, and this value is comparable with one obtained by them. It may be that the slight difference between both is reduced by taking account of the region south of $30^{\circ} \mathrm{N}$ in our case if possible. Starr and Oort (1973) obtained the value of about $-0.6^{\circ} \mathrm{C}$ per 5 years in the magnitude of a linear change, and this value is larger than ten times of the magnitude in our linear trend. Angell and Korshover (1975, 1977) also reported the $0.4-$ to $-0.5^{\circ} \mathrm{C}$ decrease about the tropospheric temperature in the global scale during the period 1958-1963 and again, in a more dense station net, the $0.3^{\circ} \mathrm{C}$ decrease in the surface- $100 \mathrm{mb}$ layer during the period 1959- 


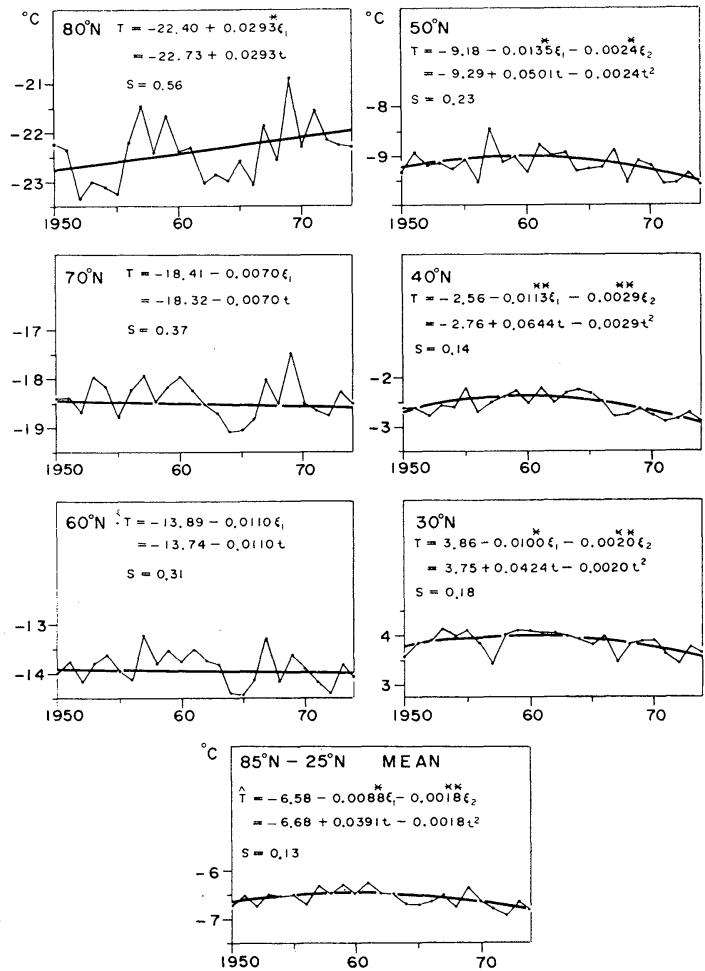

Fig. 6a The zonal- and areal-mean temperature trends in the lower layer. Thick lines show the regression curve with significance level $5 \%$ or the trend curve defined by us. Dotts and solid lines indicate year-to-year changes.

1965. The fact perhaps relates to the treated period by them and the time scale of temperature fluctuation because an equivalent-order change to the above, that is, the value of $-0.5^{\circ} \mathrm{C}$ per 6 years was found in our data for $1,000-100 \mathrm{mb}$ thickness in the period 1959-1965.

As described previously, the temperature trend was upward in the period 1900-1941 and downward in the period 1942-1972. This fact was described by Budyko (1976) too. The treated period by us just corresponds to the major part of the above cooling duration. Then, we could compare our results with one by van Loon and Williams (1976a, 1976b) in the latter period about the meridional distribution of linear regression coefficients. In our case, the first-order coefficient of Tchevychef's orthogonal polynomial should be taken as the linear regression coefficient and its unit was reduced to ${ }^{\circ} \mathrm{C}$ in 31 years used by them. The relation between both is illustrated in Fig. 7. Our values in $40^{\circ} \mathrm{N}$ and $60^{\circ} \mathrm{N}$ lie near the center between the summer and winter values by them. Those in $50^{\circ} \mathrm{N}$ and $70^{\circ} \mathrm{N}$ are close to
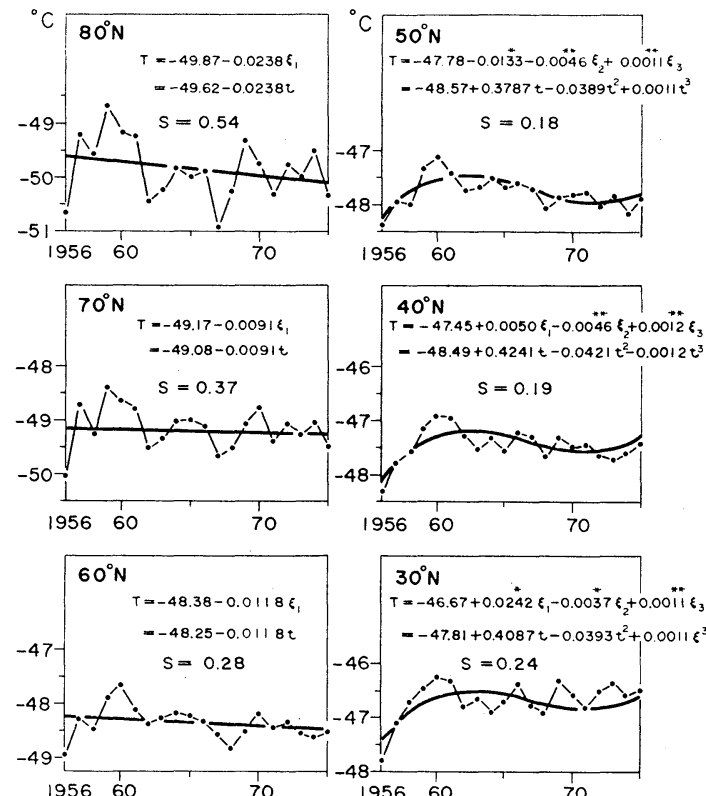

195660

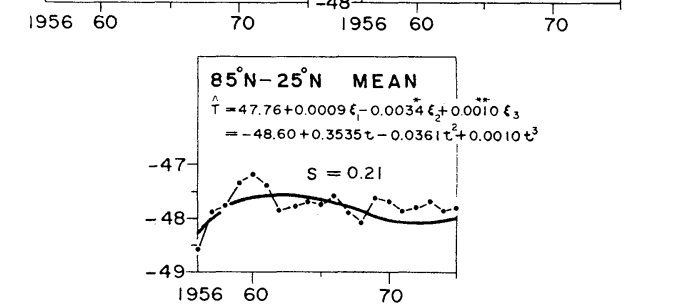

Fig. 6b As in Fig. 6a except in the upper layer.

their summer curve and that in $30^{\circ} \mathrm{N}$ to their winter curve. In spite of the differences of a data source, a period and an analysis method, it may be said that both results are very well consistent with each other beyond our expection. Our value in $80^{\circ} \mathrm{N}$ is relatively high positive. Taking account of continuity on their curve though they didn't present the tendency in $80^{\circ} \mathrm{N}$, it seems that there occurs a large discrepancy in value between both cases in $80^{\circ} \mathrm{N}$. Unfortunately, we can make no explanation for the above matter at present. On the other hand, Painting (1977) revealed the same result as us about the year-to-year variation of $1,000-500 \mathrm{mb}$ thickness in the period 1950-1973, particularly in $80^{\circ} \mathrm{N}$. He confirmed the ascending trend of surface temperature from the difference between the two periods 1961-1970 and 1971-1974 by using the data at 18 stations in high latitudes and reinforced by citing a literature which reported the decrease of sea-ice areas in the northern hemisphere. We suppose that the temperature change in the lower layer has so far 


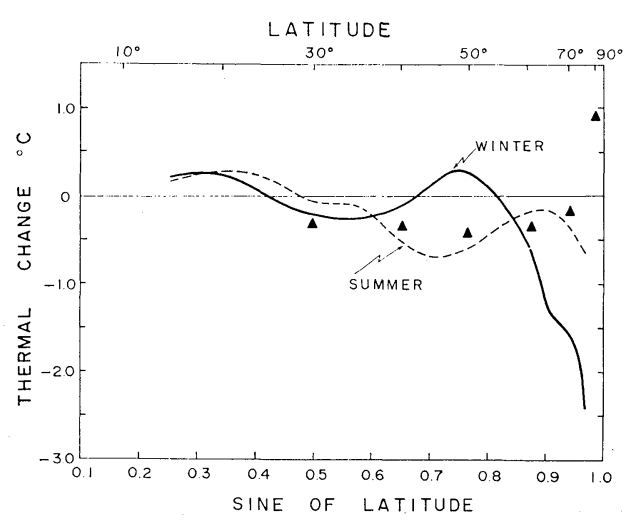

Fig. 7 The meridional distributions of the linear regression coefficients for temperature trends. Triangles represent the values in the lower layer obtained by us and solid (winter) and broken (summer) lines, curves of surface temperature trends obtained by van Loon and Williams (1976a, 1976b). Unit was reduced to ${ }^{\circ} \mathrm{C}$ in 31 years used by them.

been a warming trend in the arctic region.

Fig. $6 \mathrm{~b}$ shows aspects of the zonal- and arealmean temperature changes in the upper layer. The trend is drawn by a linearly decreasing line each latitude north of $60^{\circ} \mathrm{N}$ and by the thirdorder curve in each latitude south of $50^{\circ} \mathrm{N}$ and in the areal mean also. We can compare our areal-mean trend with the curve of the upperlayer temperature change in the north extratropics by Angell and Korshover (1977). Since not showing a numerical value in their trend, it is known by visual judgement that our trend is quite like their curve based on weighted-running-average values. As for $80^{\circ} \mathrm{N}$, our trend in the upper layer has opposite slope to that in the lower layer and its magnitude is the largest as the coefficient of linear regression of $\xi_{1}$ in comparison with the other latitudes though not so as in the lower layer. We expect that such the progress of the vertical temperature gradient in $80^{\circ} \mathrm{N}$ brought on the growth of the atmospheric instability in the arctic region and consequently much influenced on the behavior of the polar cold vortex. It is worthy of note how long the present trends are invariant there and how change occurs in them in future since the arctic cold vortex plays an important role in a cold-air outflow to the temperate zone. The trends in $70^{\circ} \mathrm{N}$ and $60^{\circ} \mathrm{N}$ are equivalent in magnitude and direction both to those in the lower layer. The trend in each latitude south of $50^{\circ} \mathrm{N}$ is quite different from that in the lower layer and opposite to the lower- layer direction in the latter years, and likewise in the areal mean also. We could divide the domain treated here into three latitudinal zones as being obvious from the above description. The first zone is $80^{\circ} \mathrm{N}$, the second zone $70^{\circ} \mathrm{N}$ and $60^{\circ} \mathrm{N}$ and the third zone south of $50^{\circ} \mathrm{N}$. The trends in the first and third zones are relatively large in a change even in the time scale treated here and it is obvious that a very-long-term trend for temperature or a climatic, change is still masked in these zones. The above matter means that a few decade years is too short to argue for a climatic change. On the other hand, the trend in the second zone has very gentle slope in spite of the steep trend in both sides of this zone. If such the feature is invariant, it is assumed that this zone is singular as to a long-term change of temperature.

\section{The trends of meridional temperature gradient}

It is well known that the meridional and zonal gradients of temperature respectively are not only elementary expressions for a temperature field but also important measures in relation to the atmospheric dynamics. We can infer some aspects for the variation of the atmospheric general circulation from these trends.

The meridional gradient of zonal-mean temperature $T_{y}$ was defined as follows.

$$
T_{y}=-\frac{\partial \bar{T}}{R \partial \varphi}=\left(\bar{T}_{s}-\bar{T}_{n}\right) / R \delta \varphi
$$

where $\bar{T}$ represents zonal-mean temperature, $R$ the earth's radius, $\delta \varphi 10^{\circ}$-latitude width in radian, and subscripts $s$ and $n$ mean the southern and northern boundaries of $\delta \varphi$ respectively.

Fig. 8a shows the trends of meridional temperature gradients in each latitude and the whole for the lower layer. The trend has a linearly descending line in each latitude north of $55^{\circ} \mathrm{N}$ and a linearly ascending line in the south two. The steeply descending trend in $75^{\circ} \mathrm{N}$ is due to the remarkably upward trend of temperature in $80^{\circ} \mathrm{N}$ as seen from Fig. 6a. The trend as a whole has a linearly descending line since the latitudinal zone with a descending trend is small in an areal rate but the coefficients are large in magnitude. According to Budyko (1977), the temperature difference between $25^{\circ} \mathrm{N}$ and $70^{\circ} \mathrm{N}$ increases in a cooling time and decreases in a warming time. The period treated here was linearly cooling time in the lower layer as seen from the linear coefficient of Tchevychef's polynomial of areal- 

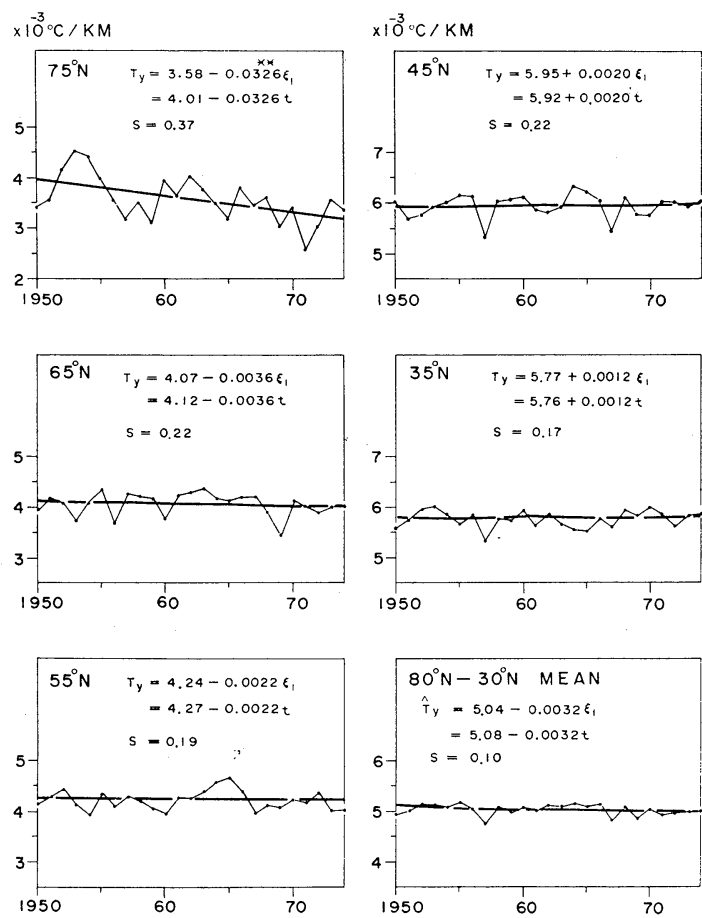

Fig. 8a The trends of mean meridional temperature gradient in the lower layer. The representation is same as in Fig. 6a except $\left(10^{-3}{ }^{\circ} \mathrm{C} / \mathrm{Km}\right)$.

mean temperature in Fig. 6a, but the mean meridional temperature gradient decreased in our case. We can see from our and his figures that the areal-mean temperature changes both take a nearly similar course to each other but both high-latitude temperature changes have an opposite trend to each other. It may be that one of the reasons for the previous discrepancy exists in the difference for estimating the temperature in high latitude.

A mean meridional temperature gradient $\hat{T}_{y}$ is often used as rough estimation of substitution for zonal available potential energy $A_{z}$ which should be essentially defined in the global temperature field and is the squared quantity on spatial deviation. Our basic data are annualmean temperature and missing in low latitudes. So it may be that the correspondence between $\hat{T}_{y}$ and $A_{z}$ is not necessarily complete in our case. Nevertheless, the $\hat{T}_{y}$ shown here is useful as substitution for $A_{z}$ since a mean meridional temperature gradient has ordinarily a maximum in the north of $30^{\circ} \mathrm{N}$. Then, we can say that the $A_{z}$ for an annual-mean stationary disturbance. of temperature has decreased in the lower layer.
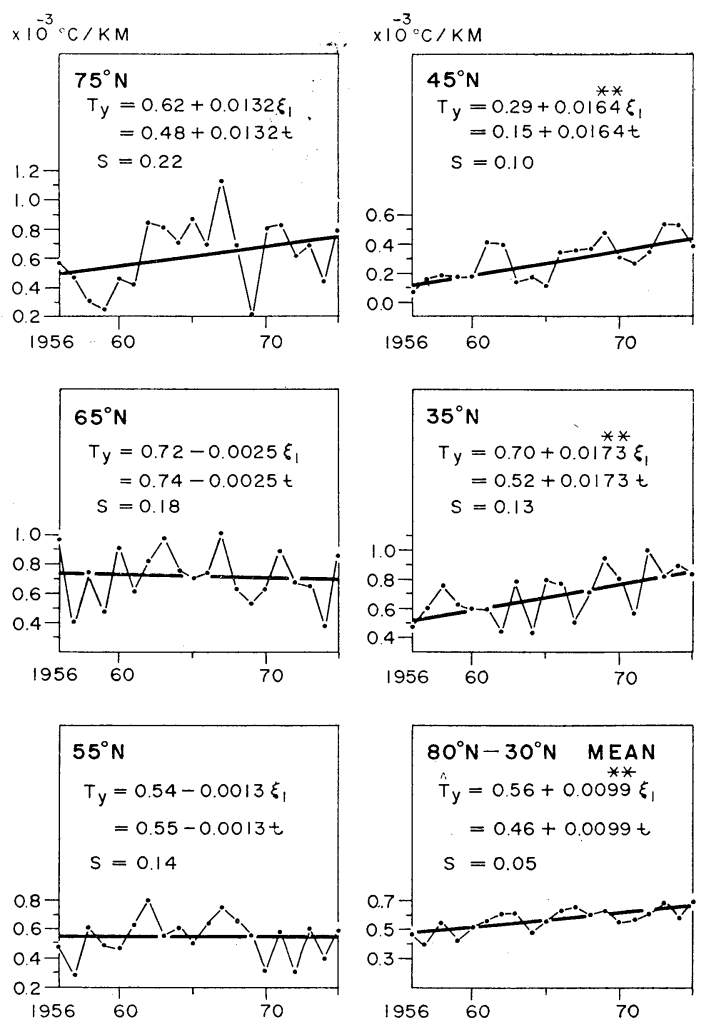

Fig. 8b As in Fig. 8a except in the upper layer.

A meridional temperature gradient $T_{y}$, in addition, is transformed into the vertical shear of the zonal component of the geostrophic wind which is an important factor in the linearized instability theory for a baroclinic wave or a cyclone wave. It will be seen from the theory that, in general, the increase of $T_{y}$ introduces the growth rate of a cyclone wave into enlargement and the reduction of $T_{y}$ reversely into repression. Accordingly, we can infer the trends of cyclone activity in the respective latitudes of Fig. $8 \mathrm{a}$ and take interest in examining whether so or not really in $80^{\circ} \mathrm{N}$, $60^{\circ} \mathrm{N}$ and $40^{\circ} \mathrm{N}$ chosen as exemplary latitudes of the previous three latitudinal zones. Now, the energy quantities in the lower troposphere are computed every wave number of spectral form within all the domain of the northern hemisphere in the daily routine of the Long Range Forecast Section of JMA since 1964 except the March, April and May in 1967, and so those quantities contain the transient effect of waves. The trends of the annual-mean eddy kinetic energy of cyclone wave lengths in the above latitudes are shown in Table 1 by the form of a linear regression 
Table 1. The linear regression formulae show the trends of the annual-mean eddy kinetic energy $\left(K_{c}\right)$ corresponding to the lower tropospheric cyclone waves in $80^{\circ} \mathrm{N}, 60^{\circ} \mathrm{N}$ and $40^{\circ} \mathrm{N}$. The unit of $K_{c}$ is $\mathrm{Kj} /$ Ton. $Y$ is a variable fixed unity to 1964 , by turns, 12 to 1975 .

\begin{tabular}{l|c|c}
\hline Lat. & Wave number & $\begin{array}{c}\text { Linear regression } \\
\text { formula }\end{array}$ \\
\cline { 2 - 3 } $80^{\circ} \mathrm{N}$ & 2 & $K_{c}=2.188-0.0075 Y$ \\
$60^{\circ} \mathrm{N}$ & 5 and 6 & $K_{c}=3.178+0.0350 Y$ \\
$40^{\circ} \mathrm{N}$ & 7,8 and 9 & $K_{c}=3.039+0.0526 Y$
\end{tabular}

formula derived from the above data and the value in 1967 was not used to obtain the formulae. The corresponding wave numbers to cyclone wave lengths are chosen as wave number 2 in $80^{\circ} \mathrm{N}, 5$ and 6 in $60^{\circ} \mathrm{N}$ and 7,8 and 9 in $40^{\circ} \mathrm{N}$, and these wave numbers are equivalent to about 3,000 to $4,000 \mathrm{~km}$ in length. It is known from Table 1 that cyclone activity was degenerative in $80^{\circ} \mathrm{N}$ and augmentative in $60^{\circ} \mathrm{N}$ and $40^{\circ} \mathrm{N}$ though being the latter half only of the period treated by us. The trends of the cyclone activity in $80^{\circ} \mathrm{N}$ and $40^{\circ} \mathrm{N}$ accord qualitatively with the inference derived from the respective trends of Fig. $8 \mathrm{a}$ on the basis of the linearized baroclinic instability theory. It seems, however, that the cyclone activity in $80^{\circ} \mathrm{N}$ did not much weaken as the inference from the trend of the meridional temperature gradient in comparison with the linear regression coefficient in Table 1, and it may be possible to explain this discrepancy by taking account of the change to a more unstable state in the arctic region as mentioned in the previous section. On the other hand, the cyclone activity in $60^{\circ} \mathrm{N}$ had a growing trend despite the decayed trend of the meridional temperature gradient. The two zonalmean temperature trends of the upper and lower layers in $60^{\circ} \mathrm{N}$ don't indicate the growing trend of an unstable state as seen from Figs. 6a and $6 \mathrm{~b}$, and hence the enlargement of the cyclone activity in $60^{\circ} \mathrm{N}$ cannot be explained in terms of the change of static stability which is another one of important factors controlling cyclone activity. We cannot give reasonable comments for the cyclone activity in $60^{\circ} \mathrm{N}$ from our data. Budyko (1977) showed an illustration with the very-high positive correlation between the secular variation of the pole-to-equator temperature difference and the amount of precipitation over the central Euro-Asia, and he suggested the effect of the above temperature difference on the variation of atmospheric circulation. It is possible for this fact to give explanation that an atmospheric circulation regime has changed to enlarge cyclone activity in connection with the variation of a meridional temperature gradient if a precipitation phenomenon is due to cyclone activity in normal state there though precipitation process is much complex.

Fig. $8 \mathrm{~b}$ illustrates the trends of the change for a meridional temperature gradient in the upper layer. The trends show that a meridional temperature difference has changed to enlarge linearly there except $65^{\circ} \mathrm{N}$ having a gently descending slope. The change of a whole-mean meridional gradient also had the linear trend enlarging a mean meridional temperature difference. The trends in $65^{\circ} \mathrm{N}$ and $55^{\circ} \mathrm{N}$ are extremely gentle in comparison with those in the other latitudes as being natural in relation to the zonal-mean temperature trends in Fig. $6 \mathrm{~b}$ and, meanwhile, the trends and those confidence coefficients in $45^{\circ} \mathrm{N}$ and $35^{\circ} \mathrm{N}$ are steeper and higher respectively rather than those in $75^{\circ} \mathrm{N}$. Following to the previous argument in the lower layer, it is stated that the $A_{z}$ in the upper layer has increased in a trend and cyclone activity has been vigorous, but the same kind of data as used in the lower layer is absent at the present time.

Generally, the meridional temperature gradient has become gentler in the lower layer and steeper in the upper layer, and this matter means in energetics that an atmospheric circulation regime has changed to lose $A_{z}$ in the lower layer and to gain $A_{z}$ in the upper layer with the process of the effect by the variation of the lower and upper meridional temperature gradients respectively.

\section{The trend of a zonal temperature gradient}

We defined the zonal gradient of temperature $T_{x}$ in the root-mean-square form as the following expression;

$$
\begin{aligned}
T_{x} & =\left[\int\left(\frac{\partial T}{R \cos \varphi \partial \lambda}\right)^{2} d \lambda / j d \lambda\right]^{1 / 2} \\
& =\left[\frac{1}{36} \sum_{i=1}^{36}\left(\frac{T_{e}-T_{w}}{R \cos \varphi \delta \lambda}\right)_{i}^{2}\right]^{1 / 2}
\end{aligned}
$$

where $R$ represents the earth's radius, $\varphi$ latitude, $\delta \lambda 20^{\circ}$-longitude interval in radian, and subscripts $e$ and $w$ mean the east and west sides of $\delta \lambda$ respectively. We can easily understand that the increase or the decrease of value for $T_{x}$ corresponds to the growth or the diminution of amplitude in zonal direction for a temperature disturbance respectively. 


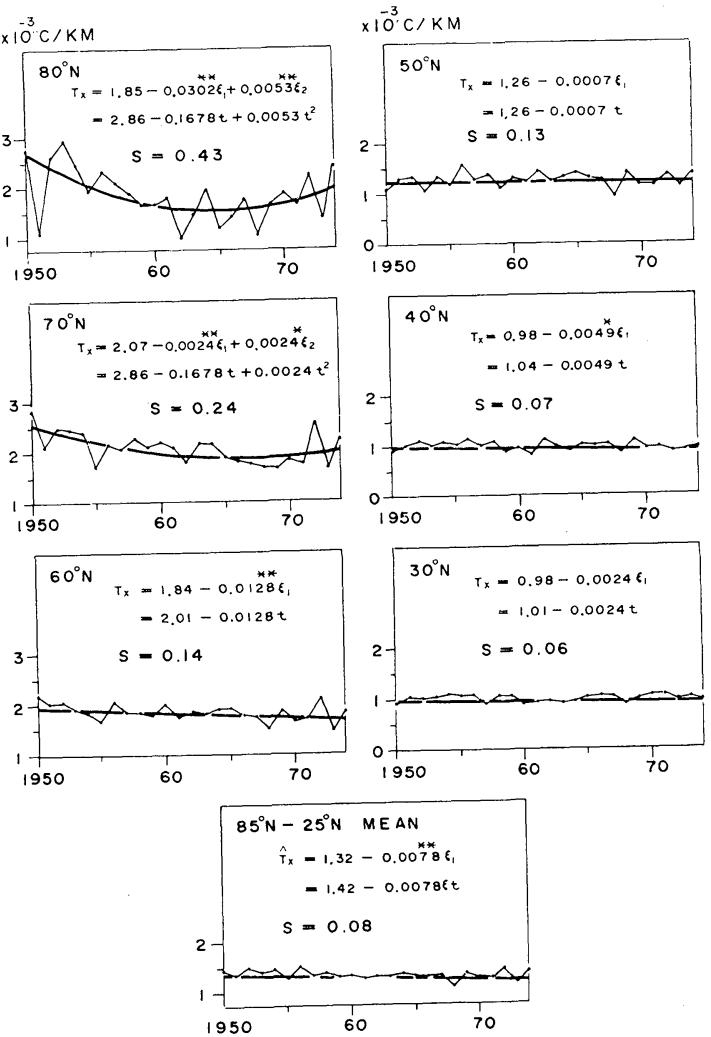

Fig. 9a The trends of zonal temperature gradient in the lower layer. The representation is same as in Fig. $6 \mathrm{a}$ except $\left(10^{-3}{ }^{\circ} \mathrm{C} / \mathrm{Km}\right)$.

Fig. 9a shows the trends of zonal temperature gradients in each latitude and the whole in the lower layer. The trends in high latitudes have a striking concave curve and so the amplitude of an annual-mean temperature disturbance has grown in the latter years though being descendant in linear approximation. The trends in the other latitudes are linear in very gentle slope comparing with that in high latitudes, and the trend in the whole also is the same aspect as that in middle latitudes. It is known that the annual-mean temperature disturbance has decayed in the lower layer as a whole.

The trends of zonal temperature gradients in the upper layer are illustrated in Fig. 9b. The trends in Fig. 9b are full of variety in shape unlike those in the figures presented previously, that is, concave curve, wavelike curve, linear line and convex curve. Consequently, it seems that the trends of $T_{x}$ in the upper layer as a whole lack unity in semblance to make remarks. As for the areal-mean zonal gradient of temperature in the upper layer then, the trend had decreasing course
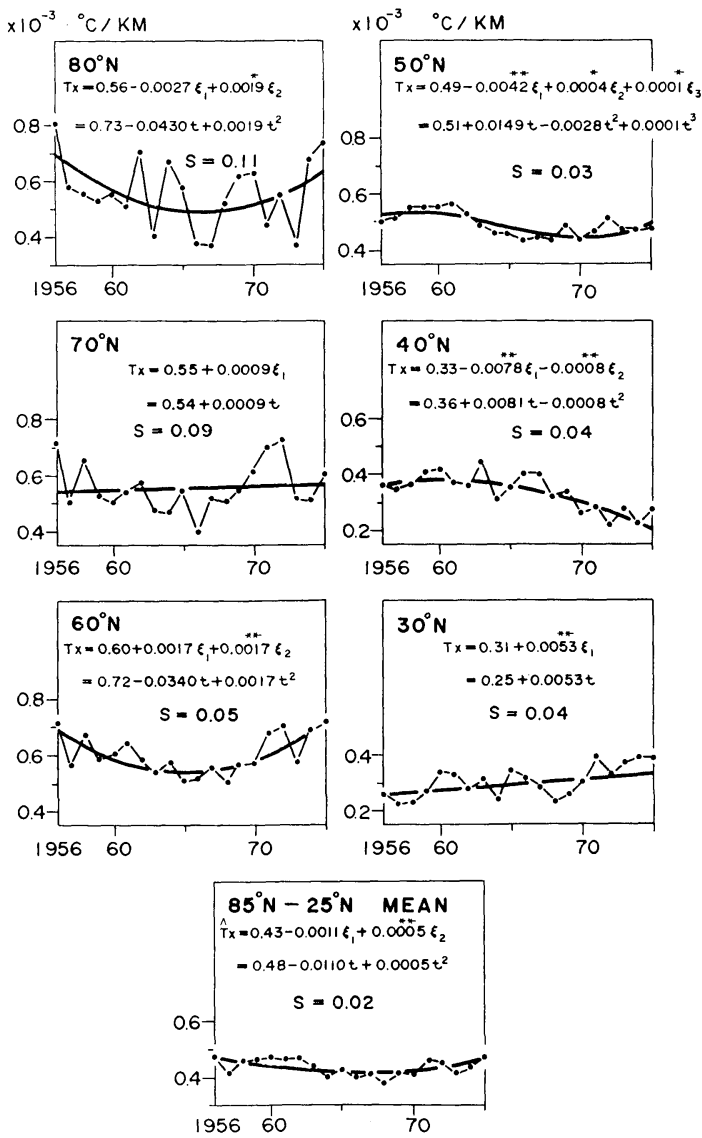

Fig. 9b As in Fig. 9a except in the upper layer.

in the beginning and increasing course in the latter years.

Angell and Korshover (1977) argued the change of spatial variability in the global-scale temperature field by a different method from us. Comparing the trend of $T_{x}$ in the lower layer with the curve at the surface in the north extratropics by them, both are quite reverse to each other. On the other hand, the comparison between both in the upper layer shows good agreement with each other as to the period 1959-1974 treated by them. Why did such the correlation occur between our and their results? One of the reasons is probably due to the difference between our and their meanings connected with spatial variability. Angell and Korshover defined spatial variability as the standard deviation of the monthly-mean values at an individual station, that is, the amplitude of temperature disturbances passing over the individual station, which is identical to the amplitude of a transient com- 


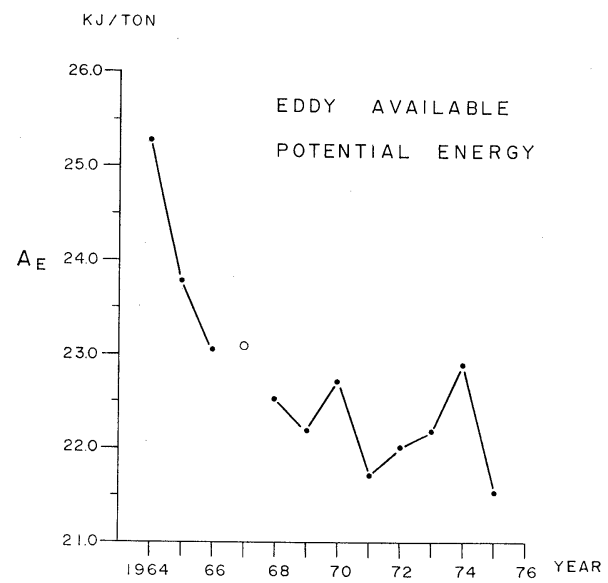

Fig. 10 Dotts and solid lines show the year-to-year variation of the eddy available potential energy in the lower troposphere of the northern hemisphere computed in the daily routine of the Long Range Forecast Section of JMA. The white circle in 1967 means a 9-month-mean value except March, April and May. The unit is $\mathrm{Kj} /$ Ton.

ponent in the disturbances of monthly-mean temperature. We, however, treated the amplitude of a stationary component itself in the annualmean temperature field. If the above argument is valid then, we could mention that the transient and stationary components in temperature disturbances had the same trend as each other in the upper layer but an opposite trend to each other in the lower layer.

Since $T_{x}$ is directly proportional to the magnitude of temperature disturbance amplitude as described previously, it is easily seen that $T_{x}$ is directly proportional to the eddy available potential energy connected with an annual-mean temperature disturbance $A_{e}$ too. Fig. 10 reveals the change course of eddy available potential energy $A_{E}$ in the lower troposphere which is computed in the daily routine of the Long Range Forecast Section of JMA as well as the eddy kinetic energy shown in the previous section. Accordingly, the values of $A_{E}$ in the figure contain even a daily transient component in temperature disturbances. Fig. 10 manifests without necessitating estimation relative to a regression curve that the $A_{E}$ has diminished since 1964 though fluctuating largely in the latter years. When adding the results by Angell and Korshover and in JMA to that by us, we can qualitatively summerize for the temperature disturbance in the lower layer after 1964 as follows. The zonal-direction amplitude of the disturbance as a whole has diminished in the total of the stationary and transient parts. The annual-mean stationary part of the disturbance also had the same trend as the above but the monthly-mean transient part of that was an opposite trend to the annual-mean stationary part.

\section{Conclusions}

We derived statistically the trends of the lower and upper temperature fields in the northern hemisphere and considered the aspects of those change through comparing both trends in the lower and upper layers with each other. It is desirable that the period to be chosen in both time series are identical to each other in such a case. Unfortunately, however, there is a slight discrepancy between the period of both time series in our case, but we expect that it is not so large as modifying qualitatively the following conclusions as to the chosen period because the period in the upper layer is identical to most of that in the lower layer.

1) The time-mean temperature field had a circumpolar wave shape with a cold-air center over the north Canada in the lower layer but an eccentric pattern with a cold-air center over the north central Siberia in the upper layer. The stationary disturbance in the upper layer was predominant in the eastern hemisphere but isothermal lines were scarcely drawn in the western hemisphere.

2) The stationary disturbances in the temperature field had an upward axis inclined nearly to $30^{\circ}$ westward in longitude.

3) As for $80^{\circ} \mathrm{N}$ in the lower layer where has always become our interest as an cold-air source, we had a high negative correlation between the zonal distributions of the zonal-mean anomalies in the time-mean temperature field and the coefficients in linear trends. In other words, it has become warmer in most of the western hemisphere, where was colder, and colder in most of eastern hemisphere where was warmer. In the upper layer, however, we had no significant correlation between both.

4) The trend of areal-mean temperature was generally downward in the lower layer and upward in the upper layer. The domain treated here was roughly classified into the following three latitudinal zones on the aspects of the trends in the lower and upper layers. The zonalmean temperature in $80^{\circ} \mathrm{N}$ had remarkably rising and falling trends in the lower and upper layers respectively, and so both trends were reverse to 
each other. The trends in the latitudinal zone south of $50^{\circ} \mathrm{N}$ were a convex curve in the lower layer and a wave shape in the upper layer, and both have become out of phase with each other recently though being not necessary so as the whole period. In spite of being located between the above two zones with a steep trend, the temperature change in $60^{\circ} \mathrm{N}$ and $70^{\circ} \mathrm{N}$ had a very gentle trend in the lower and upper layers both. It is possible that this zone is singular for a temperature change if such the trend is invariant there during very long term in the future.

5) The change of the mean meridional temperature gradient as a whole had a decrěasing trend in the lower layer and an increasing trend in the upper layer, and it is suggested energetically that zonal available potential energy has diminished in the lower layer and has increased in the upper layer. As for the latter half of our period, in addition, a cyclone activity trend was decayed in $80^{\circ} \mathrm{N}$ and growing in $40^{\circ} \mathrm{N}$, and the trends both were qualitatively consistent with results infered from the trends of the mean meridional temperature gradient in the respective latitudes on basis of the linearized baroclinic instability theory. In $60^{\circ} \mathrm{N}$, the cyclone activity had a vigorous trend despite the reduced trend of the mean meridional temperature gradient, and we have no reasonable comments for this matter in our data.

6) The zonal gradient of temperature in the lower layer has changed in a decreasing trend as a whole, and we can say energetically that the lower layer has released the eddy available potential energy $A_{e}$ connected with an annual-mean temperature disturbance. That in the upper layer as a whole had a concave-shape trend though lacking unity with respect to the latitudinal distribution and, in other words, the upper layer has captured $A_{e}$.

It is generally concluded that the temperature field has changed to become colder and flatter in the lower layer, and warmer and steeper in the upper layer as to the respectively chosen periods.

\section{Acknowledgements}

The author wishes to thank Dr. N. Saito, the Chief of the Forecast Research Division of the Meteorological Research Institute, for his encouragement. He also expresses his thanks to the staff members of the Forecast Research Division for their helpful suggestions and comments, and to Mr. E. Yajima for his laborious work of drawing the figures.

\section{References}

Angell, J. K. and J. Korshover, 1975: Estimate of the global change in tropospheric temperature between 1958 and 1973. Mon. Wea. Rev., 103, $1007-1012$.

- 2 , 1977: Estimate of the global change in temperature, surface to $100 \mathrm{mb}$, between 1958 and 1975. Mon. Wea. Rev., 105, 375-385.

Budyko, M. I., 1977: On present-day climatic changes. Tellus, 29, 193-204.

Callendar, G. S., 1961: Temperature fluctuations and trends over the earth. Quart. J. Roy. Meteor. Soc., 87, 1-11.

Friedman, D. G., 1955: Specification of temperature and precipitation in terms of circulation patterns. J. Meteor., 12, 428-435.

Japanese Standards Association, 1972: Statistical tables and formulas with computer applications. JSA-1972. (in Japanese), Chairman of Editing Committee Ziro Yamauti, Japanese Standards Association Press, Tokyo, 191-194.

Mitchell, J. M., 1963: On the world-wide pattern of secular temperature change. Proc. WMO/ UNESCO Rome 1961 Symposium: Changes of Climate, (UNESCO Arid Zone Research Series $X X)$, Paris, 161-181.

Otterman, J., 1976: Climatic change by cloudiness linked to the spatial variability of sea surface temperatures. Journal of the Franklin Institute, 302, 259-282.

Painting, D. J., 1977: A study of some aspects of the climate of the northern hemisphere in recent years. Meteorological Office Scientific Paper, No. 35, Her Majesty's Stationary Office, London, $1-25$.

Starr, V.P., and A. H. Oort, 1973: Five-year climatic trend for the northern hemisphere. Nature, 242, 310-313.

Suzuki, E., 1968: Statistical meteorology. (in Japanese), The Chijinshokan Co. Ltd., Tokyo, 93-94 and 126-127.

van Loon, H., and J. Williams, 1976a: The connection between trends of mean temperature and circulation at the surface: Part I. Winter. Mon. Wea. Rev., 104, 365-380. and - 1976b: The connection between trends of mean temperature and circulation at the surface: Part II. Summer. Mon. Wea. Rev., 104, 1003-1011.

Willett, H. C., 1950: Temperature trends of the past century. Centenary Proceedings Roy. Meteor. Soc., 195-206. 


\section{北半球温度場の最近の傾向}

森信成

気象研究所*

資料は下層大気については1950-1974の 25年間の地上気圧と 500 ミリバール高度を，上層大気については1956-1975 の 20 年間の 500 ミリバールと100ミリバールの高度を用いた。北半球 30 度以北の緯度経度 10 度ごとの格子点に与兄ら れた月平均值から，それぞれのシックネス換算の年平均気温を算出した。

变化傾向を求めるには，つぎの方法にしたがった。与兄れれた時系列をチェビシェフの直交多項式に展開して，分 散分析法による適合度検定から採用されるべき項数を決定した。この場合適合度の危険率を 5 パーセントにとった。 その後で一般形に変換された多項式をもって変化傾向の式と定義した。

まず，それぞれの期間の時間平均場を考察した。下層大気では寒気の中心は西半球側のカナダ北方にあり, 等温線 はよく見なれた極を取りまく同心円型をしていたが，上層大気では寒気の中心は東半球側の中央シベリヤ北部にあ り, 等温線は東半球のみに密集し, 西半球側には汪とんど温度傾度はみられなかった。帯状平均温度の変化傾向の型 から大まかに三つの緯度帯に分けられた。北緯 80 度は上層大気では線型下降, 下層では線型上昇を示した。北緯50度 以南の上層大気では三次曲線, 下層では二次曲線で表わされ, 最近では両者相反する傾向になってきている。上記の 非常に顕著な变化傾向をもつ緯度帯にはさむれながら, 北緯60度と70度の傾向は上層, 下層大気ともきわめてゆるや かな下降傾向を示し, 特異な緯度帯であるようにみ方る。南北温度傾度の变化傾向は上層大気では增大傾向, 下層で は減少傾向を示した。さきの時間平均場での比較から, 上層の南北温度傾度は下層の約 6 分の 1 であったが, 上層で は南北温度差は拡大し, 下層では縮少してきたことが分る。また, 面積平均された温度の変化傾向は面積率の大きい 中低緯度の变化傾向に左右されるが, 今回の場合南北温度傾度の傾向は面積率はたとえ小さくとも, 高緯度の温度変 化が大きく影響していることが知られた。東西温度傾度については, 下層大気ではどの緯度も概して隇少傾向，すな わち緯度に沿った温度場の振幅は減衰してきたことを示し，上層では緯度について多様な変化をして扣り，一概には 言うことができない。南北温度傾度, 東西温度傾度については, ェネルギー論的な立場からの考察も試みた。

要約すると, 下層大気の温度は全体的には下降傾向で, 温度場は南北・東西方向ともに平滑になるように变化し， 反対に上層大気では温度は全体的に上昇傾向で，温度場は南北・東西方向ともに傾斜が強くなってきたと言える。

* 現在所属 : 気象庁 